\title{
The Impact of Internal Control System on the Accountability Practices in Waqf Institutions: Evidence from Al Rahma International Waqf
}

\author{
Mohammed M. Ahmed Ayedh $^{1^{*}} \quad$ Dr. Nurul Nazlia Binti Jamil ${ }^{2} \quad$ Dr. Mohammad Tahir Bin Zainuddin ${ }^{3}$ \\ Faculty of Economics and Muamalat, Universiti Sains Islam Malaysia, Bandar Baru Nilai, 71800 Nilai, Negeri \\ Sembilan, Malaysia. \\ * E-mail of the corresponding author: benayedh66@gmail.com
}

\begin{abstract}
The internal control systems have several mechanisms applied to discharge the accountability through ensuring and assessing the organizational financial regulatory compliance process. This study aims at examining the impact of internal control systems' components on enhancing the accountability in Al Rahma International Waqf Institution. The sample comprises of 152 employees at the managerial level in Al Rahma International. A questionnaire survey used in the data gathering in which all the data collected at the same time from the respondents. The grouping and analyses of the questionnaire's respondents were conducted using exploratory factor analysis and multiple regression analysis in SPSS statistical tools and Maximum Likelihood Estimator (MLE) approach for data analyse. The findings show the regression analysis of both enter and stepwise method that the monitoring internal control (ICM) has a significant impact on the performance accountability practices. The analysis and findings of the data collected through this research should be of great interest to Al Rahma International and their donors. Several suggestions are highlighted for improvement based on the founded results. Several suggestions will be highlighted for improvement based on the founded results.
\end{abstract}

Keywords: internal control systems, accountability practices, Waqf Institution

DOI: $10.7176 /$ RJFA/12-16-04

Publication date:August $31^{\text {st }} 2021$

\section{Introduction}

Internal controls play a major role as one of the mechanisms to enhance the accountability in any organization. In order to ensure that the outputs (financial statements) are reliable and have a high standard quality, the inputs and the processing of them should be in a proper process and accurately. By providing high quality financial information in the financial statements this will drive to enhance the confidence of the stockholders in investment, credit, allocation of existing resources to the organization (IASB, 2008).

Furthermore, it is imperative to emphasis into the unique nature of accountability in Islam, the accountability takes wider scopes compare to the conventional accountability concepts even the one applied in the charitable institutions. In Islam, every individual human has dual accountability, one to the worldly community, and the second one is accountability to Allah almighty in the hereafter. Therefore, all the human beings are Khalifah (i.e., vicegerent) of Allah almighty and they are responsible for all funds and resources which has been entrusted in their hands; as well they are obligated to fulfill any agreement made between them (Ihsan and Adnan, 2017; Ihsan and Ayedh, 2015). This unique Islamic accountability is considered idealistic and applicable to the Waqf institutions.

The Waqf practices has been varied from country to another due to resilience nature of the Waqf institution, which leads to autonomy institutions and less restriction specially in terms of managing the Waqf institutions. The call for standardizing the Waqf practices especially the accounting and accountability have been dramatically being intension (Ayedh and Ihsan, 2013; Ihsan and Ayedh, 2015).

According to Johari et al. (2016) the corner stone in improving the Waqf organizations management system is by having effective internal control system including internal controls. An effective internal controls of income receipts and disbursement of endowment/donation, segregation of duties, qualification of staff and advisers and, and a sound internal control system on accounting disclosure and the good governance will enhance the financial and non-financial transparency level which will lead to better marketability of the Waqf organizations (Ihsan et al., 2006; Sulaiman, 2007; Karim, 2010).

Generally, funds (donations) are considered to be the main source of supply to non-profit organizations in particular and profit organizations too. According to the concepts of accounting, the accounting systems highlight the accountability instead of the profitability. Generally, the practices of nonprofit (Waqf) organizations or government agencies in making the reporting and the financial statement are according to the daily transaction instead of the gained profit. This study will use Al Rahma International Waqf Institution as an evidence to study the internal control system and the accountability practices.

Al Rahma International is one of the largest Waqf Institution which has more than 40 branches around the 
world. It was established in Kuwait at 1982. Al Rahma International received an award of transparency on 2012 and received ISO 9001:2015 on 26.06.2018 Djibouti Branch. These quality certification and award are consequences of effective internal control and show that there is a remarkable cultural of the necessity of internal controls in Al Rahma International which means that Al Rahma International is augured to discharge its accountability to its stockholders (donors). Moreover, Al Otaiqi said that Al Rahma must adhere the procedures of internal controls more efficiently and effectively.

Besides, internal controls are forced well in profit organizations when compared whit non-profit organizations. Thus, it is required to assess the efficiency and effectiveness of the internal control's practices in Waqf (non-profit) organizations as way to improve the Waqf organizations accountability and performance in general (Sulaiman, 2007). Therefore, this research aiming at examining the impact of internal control system's components on the accountability practices in Al Rahma International Waqf Institution.

The remainder of this paper is organised as follows: section two briefly presents the theoretical background of internal control system and accountability of waqf in general. Section three reviews the related literature. Section five illustrates methodology applied in the study. Next section discusses the main findings and their implications. The final section provides a detailed discussion of the findings and corresponding limitations, as well as some recommendations for future studies.

\section{Research Background}

\subsection{Internal Control Systems on Profit and Non-Profit Organization}

The Internal control system identified as one of the main elements to assure good management practices which considered as essential elements for any organization to operate in good practices, including non-profit organizations. The internal control has been defined by the Committee of Sponsoring Organizations of the Treadway Commission (COSO) as a process, effected by the entity's board of directors, managing and other personnel-designed in order to give reasonable assurance about the entity's objectives achievement with regard to: (1) reliability of financial reporting; (2) effectiveness and efficiency of operations; and (3) compliance with applicable laws and regulations. These three main objectives are applicable to all types of organizations including non-profit organizations.

According to COSO (2013) the internal control components are divided into five components which need to be focus which are: (1) control environment;(2) risk assessment; (3) control activities; (4) information and communication; and (5) monitoring activities. Spillan and Ziemnowicz (2011) stated that it is important all of these five components to be reviewed quarterly of its implementations to make sure of the good practices and its relevance.

Despite all these five components of internal control, the most basic and important component that is related to daily management of cash flow are control activities. In the latest edition of COSO (2012) control activities basically can be divided into five activities which are: (1) segregation of duties; (2) authorization and approval; (3) verification and reconciliation; (4) physical control; and (5) supervisory check. Petrovits et al. (2011) stated that when the internal control practices in a nonprofit organization appropriately, it can prevent insufficiencies reflected through unproper practices of the internal control that may affect in the public support reduction particularly by donors.

Internal controls (IC) are part of the internal control system within an organization. As these internal control systems shape the procedures to ensure sound of effectiveness in the organization operations and protect the organization from any fraudulent or opportunistic behavior and preserve acquiescence with rules and laws. Particularly, the internal controls (IC) are concerning direct to control the financial process to enhance the reliability and credibility of financial reporting (Kewo and Afiah, 2017; Krishnan, 2005). Internal controls embrace policies and procedures, which implemented by the company to ensure conducting its business efficiently, including the regulatory compliance which prevent and detect frauds and errors, thereby covering not only the controls over reliable reporting of financial statements.

\subsubsection{Control Environment:}

The control environment is the component of internal control. It is a set of ethics, structures, and procedures which provide the basis of functioning internal control within the organization. There are some important factors included like ethical values, integrity, capability of the employees and the philosophy of management within the organization. The control environment component provides the required basis for the rest components to shape on the systems of the internal controls (COSO, 2013).

\subsubsection{Risk Assessment:}

Risk assessment component is usually used for identifying any expected danger within the system. In order to make sure that the risk assessment is operative and effective, preventative measures are to be put into place by launching clear objectives. The risk assessment identifies and analyzes possible risks whether internally or externally. It manages risk by developing accurate procedures to accomplish consistent objectives within the organization. Risk assessment always takes change into consideration within the objectives set forth by 
Enterprise Risk Management - (Integrated Framework, 2004).

\subsubsection{Control Activities:}

Control activities are performed at the entire company or organization levels, at several stages within its units and processes. They are continuously developed in order to support in the monitoring process which include policies, procedures and practices advanced to increase risk management strategies. Specific control activities comprise separation of duties, verifications, reconciliations and physical security of assets. These policies are designed to ensure that management directives are fulfilled (COSO, 2013).

\subsubsection{Information and communication}

Information must be identified, captured and communicated timely and efficiently and achieved through this internal control component. It is designed to give employees the ability of carrying out their responsibilities in the best possible manner. Information had better be communicated externally to all parties whom involved in the organization. The communication of information allows control activities and employee responsibilities to be more effectively (COSO, 2013).

\subsubsection{Monitoring activities}

The monitoring component is considered as the most important internal control components due to the major role it plays such as evaluating the performance of the internal control components, certifying that they are efficiently operating. Also, it consists of permitting the managers clear guidelines of their responsibilities so that they can achieve their duties effectively. It also comprises the evaluations performance through auditors and other external parties, making sure that the organization is conducting the business's operations properly (COSO, 2013).

\subsection{The Practice of Accountability on Non-Profit Organization (Waqf)}

In terms of the impact of Internal Controls (ICs) on the accountability practice in Waqf institutions, Ihsan et al. (2017) provided insights into how accountability is perceived and discharged by the mutawalli (Waqf trustee) in managing a Waqf. Meanwhile, Effah (2011) found that the compliance level and other procedures of the financial management, and the existence of internal control systems in the hospitals.

The complex relationships between the accountability facing nonprofit organizations in meeting the responsibilities to donors, consumers, community, associates and volunteers. These responsibilities to multiple stakeholders give huge pressure to nonprofits organization which tend to prioritize accountability to donors, foundations and governments over accountability to clients and the populations being served by the organization. Nevertheless, in regards of looking for the voices of people which they serve, nonprofit institutions might take over their tasks and enhance their institutions. Advanced efforts to make a priority of the accountability downward in the focus of different stakeholders (donors) requires indicating the importance of downward accountability as a critical issue facing the nonprofit sector.

Regardless of the challenges related with addressing descending accountability, the non-profit managements seek to enhance accountability to the society they assist should firstly clarify the way mechanisms line up with the values and mission of the organization. Leaders of nonprofit had better similarly to set up a procedure that allows clients to bring up complaints, identifying even negative perspectives could be relevant to organizational improvement (Mercelis et al., 2016). Developing the mechanisms for downward accountability offers the people served by nonprofits both choice and voice in the services they receive. By firming up downward accountability, leaders of nonprofit can enhance the organizations and make sure they achieve the responsibilities which were handed over to them.

\section{Literature Review}

\subsection{Studies to explore the Internal Control Systems Practice on Non-Profit Organization}

Abraham (2007), Hermanson et al. (2012) and Abdulkadir (2014) explore the internal control practices on Nonprofit organization, the studies found that in non-profit organization it is important to have internal control, however it is more challenging compared to the profit organizations. Study focusing on Waqf by Johari et al. (2016), the study investigated the internal control issues of Waqf institutions globally. They found that internal controls establish a process on how an organization handles in receiving and reporting money and, administrative and management tasks.

\subsection{Studies related to the Relationship Between Internal Controls Systems Practice and Performance of Non-Profit Organization}

Said et al. (2013) examined the financial performance impacts on the program quality in mosque. The study conducts a cross sectional data analysis to examine factor contributes to mosque financial performance. Regression analysis results revealed that good internal control and active participation of mosque committees in fund raising activities improve mosque financial performance. This study also discovered that strong financial performance facilitates the mosque to conduct more quality and quantity program. 
Michino (2011), Said et al. (2013) and Mahadeen et al. (2016) investigated the role of the internal control system on organizational performance. Their findings indicated a positive role on performance.

Another study in Malaysian Mosques employees by Jamaliah et al. (2013) aimed to observe the efficiency of internal control system, financial management and the practices of accountability in Malaysian mosques. The performance of internal control system in Malaysian Mosques has improved due to the understanding of the financial management practices in non-profit (Waqf) institutions.

Ihsan et al. (2017) addressed the accountability practice in a Waqf institution to provide insights into how accountability is perceived and discharged by the mutawallī (Waqf trustee) in managing a Waqf. The findings disclose that the belief in dual accountability, to Allah and human beings, has strengthened the mutawalli's awareness of the accountability importance. This study concludes that the holistic accountability practiced by Dompet Dhuafa is an integrative process which does not only encompass fulfilling upward and downward accountability, but also gets involved in a commitment to preserve organizational values.

Ayedh et al. (2019) explored case studies based on numerous case study willing to make a full understanding for the practices of the Waqf accountability in Malaysia. The data were collected based on related manual guideline, official web sites, financial reports and statements of the SIRCs in order to get the understanding on current accountability practice for Waqf institutions in Malaysia. The study's findings emphasis that the generating of improvement particularly subject to the accountability management. The State Islamic Religious Council (SIRCs) in Malaysia is responsible of handling the assets of Waqf which were given to them. Recently, some studies have taken into the operational of the Waqf management in the State Islamic Religious Councils. The provided results give more importance to the recent researches.

Kamarubahrin and Ayedh (2018) evaluated present the Waqf organization practices based on Middle East, Asia and other particular non-Muslim countries experience. The critical assessment demonstrates that Singapore Waqf experience was astonishing impressive in terms of transparency, quality services, gain public confidence in Waqf management and Waqf investment. On the other hand, the experience of Kuwait records outstanding performance because of the less interruption by the government and establishes the sound of governance, internal control and accountability tools. Furthermore, in the Muslim minority communities Waqf practices are bouncing and response to the community's needs compare to the majority Muslim countries.

Ayedh et al. (2018) investigated that the way Mutawallis (awqaf managers) in Yemen perceive their responsibility and how they release it. This study used a comprehensive survey to collect the data. The findings released that the Mutawallis are mainly comprehended to be responsible to the government awqaf institutions, after the responsibility to the waqif (donor). These perceptions were influenced by the organizational rules and values governing the Waqf. Lastly, the most important mechanism used in discharging Waqf accountability is the regular issuance of financial annual reports which comes after the completion of government auditing requirements, waqif requirements, as well as the customer's satisfaction. Furthermore, according to the results the Mutawalli is usually held accountable to the waqif (donor) therefore, the accountability to the government awqaf institutions is more perceptible. Putting in order the government in discharging Waqf accountability wouldn't be surprising.

Based on the above review, the main literature gab could be summarized in two main points. First, there is a huge gab in terms of studies focusing on International and cross countries Waqf institutions (i.e., Al Rahm International). There is lack of studies exploring the role of internal control and accountabilities practices. It is worth mentioning that there is a room for a research to expand the existing studies on internal control systems and the waqf accountability.

\section{Model and hypotheses development}

The results of previous studies reveals that several variables (internal control components) have impact on the accountability practices. The accountability theory explains in what way that the observant required to justify his or her behaviors and deeds to others and to be accountable for all behaviors, deeds, decisions, and judgments which affect others (Vance Lowry and Eggett, 2015).

In addition, the accountability theory applied in this study to explain the research model. This theory has been used in several studies such as Ihsan and Adnan (2009); Ihsan et al. (2017); Ayedh et al. (2019). Figure 1 illustrates the proposed hypotheses based on the literature review and the accountability theory:

H1: There is a significant impact of the control environment on the accountability practice in Al-Rahma international.

H2: There is a significant impact of the risk assessment on the accountability practice in Al-Rahma international.

H3: There is a significant impact of the control activities on the accountability practice in Al-Rahma international.

H4: There is a significant impact of the information and communication on the accountability practice in AlRahma international. 
H5: There is a significant impact of the monitoring on the accountability practice in Al-Rahma international.

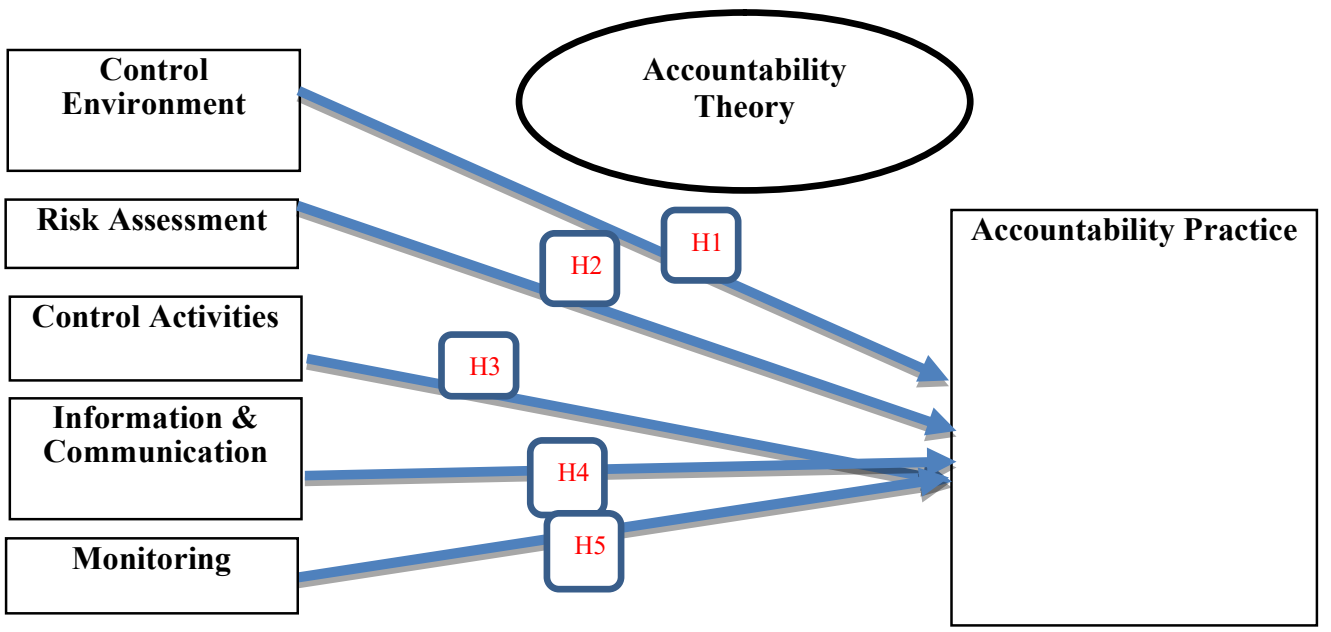

Figure 5.1: Research Model

\section{Research Method}

The current study focuses on the the role of the internal control in Waqf organizations particularly in Al Rahma International. Particularly, the target population is the financial staffs, internal auditors, and high managerial staffs in Al Rahma International. The questionnaire was distributed to 342 employees in all branches of $\mathrm{Al}$ Rahma. Out of the distributed questionnaires, 152 were returned and completed for analysis with response rate $\%$ 44, which is within the acceptable rate (Dusuki and Abdullah, 2007). The questionnaire items were derived from the previous studies. It was constructed structured into three sections the demographic (age, gender, education, location, position). The second section is the internal controls divided into five main parts control environment, risk assessment, control activities, information and communications, and monitoring which will be set according to the Likert scale question. The third section in the questionnaire is addressing the accountability practices. The measurement for these three sections was made on a five points Likert scale $(1=$ Strongly Disagree and $5=$ Strongly Agree). In addition, the questionnaire was made in English and Arabic languages and were distributed in both based on the language of the country. The collected data was analyzed using exploratory factor analysis and multiple regression analysis in SPSS statistical tools.

\section{Findings and Discussions}

\subsection{Demographic Analysis}

Among the distributed 342 questionnaires according the tablet sample and only 152 questionnaires were returned and completed for analysis. Between the returned 152 questionnaires, there was $145(95.4 \%)$ male and $7(4.6 \%)$ females. The highest participation percentage (56.6\%) was from the age group (34-41) years, while the lowest participation percentage $(2 \%)$ was from those within the age group $(<25)$ years. In addition, most of the respondents were those holding Bachelor degree (55.9\%). Furthermore, the employees were mostly having 6 to 10 years of experience $(36.8 \%)$. As for the sector, the highest percentage $(37.1 \%)$ was from industrial organizations. The participants were most $(60.3 \%)$ working in organizations which have been established $>20$ years. 
Table 5.1: Demographic Descriptive Analysis

\begin{tabular}{|l|l|l|l|l|l|}
\hline \multirow{5}{*}{ Education } & & Frequency & Percent & $\begin{array}{l}\text { Valid } \\
\text { Percent }\end{array}$ & $\begin{array}{l}\text { Cumulative } \\
\text { Percent }\end{array}$ \\
\hline \multirow{5}{*}{ Experience } & Diploma & 11 & 7.2 & 7.2 & 7.2 \\
\cline { 2 - 6 } & Undergraduate degree & 85 & 55.9 & 55.9 & 63.2 \\
\cline { 2 - 6 } & Postgraduate & 56 & 36.8 & 36.8 & 100.0 \\
\cline { 2 - 6 } & From 1 to 5 years & 20 & 13.2 & 13.2 & 13.2 \\
\cline { 2 - 6 } & From 6 to 10 years & 56 & 36.8 & 36.8 & 50.0 \\
\cline { 2 - 6 } & From 11 to 15 years & 41 & 27.0 & 27.0 & 77.0 \\
\cline { 2 - 6 } & From 16 to 20 years & 24 & 15.8 & 15.8 & 92.8 \\
\cline { 2 - 6 } & From 21 to 25 years & 11 & 7.2 & 7.2 & 100.0 \\
\hline \multirow{5}{*}{ Position } & Male & 145 & 95.4 & 95.4 & 95.4 \\
\cline { 2 - 6 } & Female & 7 & 4.6 & 4.6 & 100.0 \\
\cline { 2 - 6 } & Director General & 6 & 3.9 & 3.9 & 3.9 \\
\cline { 2 - 6 } & Finance Manager & 10 & 6.6 & 6.6 & 10.5 \\
\cline { 2 - 6 } & Accountant & 17 & 25.7 & 25.7 & 36.2 \\
\cline { 2 - 6 } & Internal Audit & 80 & 52.6 & 52.6 & 100.0 \\
\cline { 2 - 5 } & Others: & & 11.2 & 47.4 \\
\hline
\end{tabular}

\subsection{Exploratory Factor Analysis}

The exploratory factor analysis is undertaken in this study to properly explore the relationship between dependent and independent variables.

Table 5.2: Summary of Exploratory Factor Analysis

\begin{tabular}{|l|l|l|l|l|l|}
\hline & $\begin{array}{l}\text { Number } \\
\text { of items }\end{array}$ & $\begin{array}{l}\text { KMO } \\
\text { Value }\end{array}$ & $\begin{array}{l}\text { Bartlett's } \\
\text { Test }\end{array}$ & \multicolumn{2}{|l|}{ Factor Loading } \\
\hline Control Environment & 12 & 0.791 & 0.000 & $\begin{array}{l}\text { General attributes } \\
\text { IC Envir. } \\
2.297^{*}(0.791)^{* *}\end{array}$ & $\begin{array}{l}\text { Specific attributes } \\
\text { IC Envir. } \\
2.068(0.800)\end{array}$ \\
\hline Risk Assessment & 12 & 0.848 & 0.000 & $\begin{array}{l}\text { Financial ICR } \\
3.611(0.791)\end{array}$ & $\begin{array}{l}\text { Non-Financial ICR } \\
1.922(0.800)\end{array}$ \\
\hline Control Activities & 14 & 0.848 & 0.000 & $\begin{array}{l}\text { Indirect ICA } \\
2.946(0.781)\end{array}$ & $\begin{array}{l}\text { Direct ICA } \\
2.380(0.788)\end{array}$ \\
\hline $\begin{array}{l}\text { Information and } \\
\text { Communications }\end{array}$ & 8 & 0.745 & 0.000 & $2.243(0.771)$ & \\
\hline Monitoring & 9 & 0.817 & 0.000 & $3.283(0.751)$ & \\
\hline Accountability Practices & 10 & 0.782 & 0.000 & $3.285(0.790)$ & \\
\hline
\end{tabular}

* Eigenvalues, ** Cronbach's Alpha

The Variables attributes were measured by 65 items. As shown in Table 5.2 only one factor has an Eigenvalue greater than one. As the minimum reliability of the constructs is above 0.7 , it can be assumed that all constructs of the instrument produced an acceptable reliability level. In addition, the findings of the anti-image and communalities are showing good fitting of all items.

\subsection{Regression Analysis}

Before testing the research models and hypothesis, several model validity and reliability tests has been done (e.g., normality, multicollinearity).

The regression analysis was performed by regressing the outcome components of exploratory factor analysis. Therefore, the following regression model was tested:

\section{$\operatorname{AccP}^{1}=\beta_{0}+\beta_{1}$ ICE.G $^{2}+\beta_{2}$ ICE.S $^{3}+\beta_{3}$ ICR.Fin $^{4}+\beta_{4}$ ICR.Nfin $^{5}+\beta_{5}$ ICA.Ind $^{6}+$ \\ $\beta_{6} \mathrm{ICA} \operatorname{Dir}^{7}+\beta_{7} \mathrm{ICI}^{1}+\beta_{8} \mathrm{ICM}^{2}+\varepsilon^{3}$}

\footnotetext{
${ }^{1}$ AccP: Accountability Practices.

${ }^{2}$ ICE.G: General Internal Control Environment.

${ }^{3}$ ICE.S: Specific Internal Control Environment.

${ }^{4}$ ICR.Fin: Financial Risk Assessment.

${ }^{5}$ ICR.Nfin: Non-financial Risk Assessment.

${ }^{6}$ ICA.Ind: Indirect Internal Control Activities.

7 ICA.Dir: Direct Internal Control Activities.
} 
The table 5.3 shows that at significant level 0.10 , two independent variables were shows statistically significant, first IV is the indirect internal control activities (ICA.Ind) $(\beta=0.207, \mathrm{p}=0.061)$ and non-financial risk assessment (ICR.Nfin) $(\beta=0.181, \mathrm{p}=0.055)$ had significant impact on performance accountability practice (APP). Second at 0.05 significant level, the specific internal control environment (ICE.S) $(\beta=0.131, \mathrm{p}=0.031)$, and direct internal control activities (ICA.Dir) had a significant impact on performance accountability practice (APP) $(\beta=0.207, \mathrm{p}=0.061)$. Where at 0.01 significant level, there is only Monitoring (ICM) has a significant impact on performance accountability practice (APP) $(\beta=0.301, \mathrm{p}=0.002)$.

Based on the enter method regression analysis, the General internal control environment (ICE.G), Financial Risk Assessment (ICR.Fin), and Information and communication (ICI) had no statistically significant impact on performance accountability practice (APP).

Table 4.3: Regression Analysis using Enter Method

APP $=\beta_{0}+\beta_{1}$ ICE.G $+\beta_{2}$ ICE.S $+\beta_{3}$ ICR.Fin $+\beta_{4}$ ICR.Nfin $+\beta_{5}$ ICA.Ind +

$\beta_{6}$ ICA.Dir $+\beta_{7}$ ICI $+\beta_{8}$ ICM $+\varepsilon$

\begin{tabular}{|c|c|c|c|c|}
\hline \multirow[t]{2}{*}{ Variables } & $\begin{array}{l}\text { Standardized } \\
\text { Coefficients }\end{array}$ & \multirow{2}{*}{$\begin{array}{l}\text { Std. } \\
\text { error }\end{array}$} & \multirow[t]{2}{*}{ t-value } & \multirow[t]{2}{*}{ Sig. vale } \\
\hline & $\operatorname{Beta}(\beta)$ & & & \\
\hline (Constant) & 0.001 & 0.069 & 0.119 & 0.330 \\
\hline General internal control environment (ICE.G) ${ }^{\mathrm{b}}$ & 0.169 & .085 & .015 & 0.988 \\
\hline Specific internal control environment (ICE.S) ${ }^{\mathrm{b}}$ & 0.131 & .078 & 2.172 & $0.031 * *$ \\
\hline Financial risk assessment (ICR.Fin) $^{\mathrm{b}}$ & 0.183 & .080 & 1.651 & 0.101 \\
\hline Non-Financial risk assessment (ICR.Nfin) ${ }^{\mathrm{b}}$ & 0.181 & .095 & 1.938 & $0.055^{* *}$ \\
\hline Indirect internal control activities (ICA.Ind) ${ }^{\mathrm{b}}$ & 0.207 & .096 & 1.887 & 0.061* \\
\hline Direct internal control activities (ICA.Dir) ${ }^{b}$ & 0.079 & .095 & 2.171 & $0.032 * *$ \\
\hline Information and communication $(\mathbf{I C I})^{\mathrm{b}}$ & 0.329 & .090 & -.875 & 0.383 \\
\hline Monitoring $(\mathbf{I C M})^{\mathrm{b}}$ & 0.001 & .107 & 3.084 & $0.002 * * *$ \\
\hline $\begin{array}{ll}\mathrm{R}^{2} & 0.309 \\
\mathrm{~F} & 7.987 \\
\end{array}$ & $\begin{array}{l}\text { Adjusted R }{ }^{2} \\
\text { Sig. F }\end{array}$ & $\begin{array}{l}0.2 \\
0 .\end{array}$ & & \\
\hline
\end{tabular}

a. Dependent Variable: Performance Accountability Practice (APP), b. Predictors for all independent variables $* * *$ Significant at 0.01 level (2-taild), ** Significant at 0.05 level (2-taild), * Significant at 0.10 level (2taild)

The study also, applied stepwise regression method in order to improve the findings of the regression analysis. The findings of stepwise regression analysis for the same model are presented in table 4.4 Only three internal control components show statistical impact. First, monitoring (ICM) has a significant impact on performance accountability practice $(\mathrm{APP})(\beta=0.352, \mathrm{p}=0.000)$ at 0.001 significant level. In addition, the financial risk assessment (ICR.Fin) $(\beta=0.183, \mathrm{p}=0.014)$ and Specific internal control environment (ICE.S) $(\beta=$ $0.181, \mathrm{p}=0.015$ ) at 0.05 significant level. For the other independent variables (ICE.G, ICR.Nfin, ICA.Ind, ICA.Dir, ICI) have been Excluded from the regression model to overcome the overlapping issue of among the independent variables.

\footnotetext{
${ }^{1}$ ICI: Information and Communication.

${ }^{2}$ ICM: Monitoring.
} 
Table 4.4: Regression Analysis using Stepwise Method

APP $=\beta_{0}+\beta_{1}$ ICE.G $+\beta_{2}$ ICE.S $+\beta_{3}$ ICR.Fin $+\beta_{4}$ ICR.Nfin $+\beta_{5}$ ICA.Ind +

$\beta_{6}$ ICA.Dir $+\beta_{7}$ ICI $+\beta_{8}$ ICM $+\varepsilon$

\begin{tabular}{|c|c|c|c|c|}
\hline \multirow[t]{2}{*}{ Variables } & $\begin{array}{l}\text { Standardized } \\
\text { Coefficients }\end{array}$ & \multirow{2}{*}{$\begin{array}{l}\text { Std. } \\
\text { error }\end{array}$} & \multirow[t]{2}{*}{ t-value } & \multirow[t]{2}{*}{ Sig. vale } \\
\hline & $\operatorname{Beta}(\beta)$ & & & \\
\hline (Constant) & 0.021 & 0.069 & 0.119 & 0.630 \\
\hline Monitoring $(\mathbf{I C M})^{\mathrm{b}}$ & 0.352 & 0.075 & 4.663 & $0.000 * * *$ \\
\hline 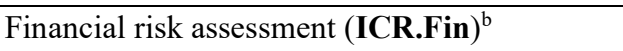 & 0.183 & 0.073 & 2.499 & $0.014 * *$ \\
\hline Specific internal control environment (ICE.S) ${ }^{\mathrm{b}}$ & 0.181 & 0.074 & 2.464 & $0.015 * *$ \\
\hline $\begin{array}{c}0.273 \\
18.484\end{array}$ & $\begin{array}{l}\text { Adjusted } \\
\text { Sig. F }\end{array}$ & & & \\
\hline
\end{tabular}

a. Dependent Variable: Performance Accountability Practice (APP)

b. Predictors for all independent variables

c. Excluded variable, ICE.G, ICR.Nfin, ICA.Ind, ICA.Dir, ICI

$* * *$ Significant at 0.01 level (2-taild), ** Significant at 0.05 level (2-taild), * Significant at 0.10 level (2taild)

By looking to findings of both methods enter and stepwise above, it worth to note that monitoring internal control (ICM) and specific internal control environment (ICE.S) were having statistically significant role on performance accountability practice (APP) in both methods (enter and stepwise). Furthermore, using stepwise method had weaken and excluded the role non-financial risk assessment (ICR.Nfin), direct internal control activities (ICA.Dir). Where the Financial risk assessment (ICR.Fin) has shown significant impact on performance accountability practices (APP).

\section{CONCLUSION}

Based on the above discussion, it can be seen that the practices of internal controls in AL-Rahma are good and being implemented with high ethics and efficiency. The findings show that AL-Rahma's environment has an efficiently internal control system and a significant atmosphere of mutual trust. The finding illustrates that ALRahma gives the risk assessment a significant priority in implementing any activities which indicates that ALRahma is aware of the importance of policies and procedures in conducting its activities. The findings show that the communication process is efficiently applying between the AL-Rahma 's facilities. The findings also show that the internal control system is being monitoring and reviewing regularly by AL-Rahma management and a corrective action has been made to the findings and recommendations. The findings show that the accountability theory can explain the accountability practices in terms of performance and evaluation which mean that $\mathrm{Al}$ Rahma International internal control practices are more focus on the physical and financial control practices. The findings illustrate that waqf activities in AL-Rahma have been increasing in the past years as a result of the highly implementing of the accountability practices.

The main contribution of the study is to provide an overall view of the importance role of internal control system playing in AL-Rahma international Waqf institution. These areas were not covered by previous studies. Hence, it would be providing evidence for a better understanding on the internal control systems in AL-Rahma international Waqf institution and its impact on the accountability practices. Hopefully, the result of this study will also benefit donors who are the main element in any non-profit organizations and Waqf. Similarly, this study will be as advantage for AL-Rahma International and its beneficiaries of AL-Rahma activities.

\section{References}

Abdulkadir, H. S. (2014). Challenges of implementing internal control systems in Non-Governmental Organizations (NGO) in Kenya: A case of Faith-Based Organizations (FBO) in Coast Region. Journal of Business and Management, 16(3), 57-62.

Abraham, A. (2007). An embedded model for understanding the development of accounting control systems in a nonprofit organisation.

Amidu, M., Effah, J., \& Abor, J. (2011). E-accounting practices among small and medium enterprises in Ghana. Journal of Management Policy and Practice, 12(4), 146-155.

Committee of Sponsoring Organizations of the Treadway Commission. (2004). Enterprise risk managementintegrated framework: executive summary \& framework. American Institute of Certified Public Accountants (AICPA).

Dusuki, A. W., \& Abdullah, N. I. (2007). Maqasid al-Shariah, Maslahah, and corporate social responsibility. American Journal of Islamic Social Sciences, 24(1), 25. 
Hermanson, D. R., Smith, J. L., \& Stephens, N. M. (2012). How effective are organizations' internal controls? Insights into specific internal control elements. Current Issues in Auditing, 6(1), A31-A50.

IASB, E. D. (2008). An improved conceptual framework for financial reporting.

Ihsan, H., \& Adnan, M. A. (2009, October). Waqf accounting and the construction of accountability. In International Conference in Waqf Laws and Management: reality and propects. Kuala Lumpur.

Ihsan, H., \& Ayedh, A. (2015). A proposed framework of Islamic governance for awqaf. Journal of Islamic Economics, Banking and Finance, 11(2), 117-133.

Ihsan, H., Ayedh, A.M. and Shahul, H.M.I. (2006) "Towards the betterment management and transparency of Waqf institutions: Lessons from the Charity Commission, UK.”, Al-Risalah, Vol.6, pp. 27-46.

Ihsan, H., Sulaiman, M. B., Mohammad Alwi, N., \& Adnan, M. (2017). A study of accountability practice in Dompet Dhuafa Waqf of Indonesia. Journal of King Abdulaziz University: Islamic Economics, 30(2).

Islamic accounting. Unpublished Phd thesis. University of Dundee, UK.

Johari, N., Mustaffha, N., \& Hameed, L. B. M. (2012). Internal Control Issues in Waqf Management: Insights from the Literature. Social Sciences.

Karim, S. A. (2010). Contemporary Shari'a Compliance Structuring for the Development and Management of Waqf Assets in Singapore. Kyoto Bulletin of Islamic Area Studies, 3(2), pp. 143-164.

Kewo, C. L., \& Afiah, N. N. (2017). Does Quality of Financial Statement Affected by Internal Control System and Internal Audit? International Journal of Economics and Financial Issues, 7(2), 568-573.

Krishnan, J. (2005). Audit Committee Quality and Internal Control: An Empirical Analysis. Accounting Review $.80,649-675$.

Mercelis, F., Wellens, L., \& Jegers, M. (2016). Beneficiary participation in non-governmental development organisations: A case study in Vietnam. The Journal of Development Studies, 52(10), 1446-1462.

McNally, J. S. (2013). The 2013 COSO Framework \& SOX Compliance: One approach to an effective transition. Strategic Finance, 6, 1-8.

Petrovits, C., Shakespeare, C., \& Shih, A. (2011). The causes and consequences of internal control problems in nonprofit organizations. The Accounting Review, 86(1), 325-357.

Rittenberg, L. E. (2013). COSO 2013 a reflection of the times: the long-awaited Internal Control-Integrated Framework update aims to help organizations better design and implement controls, with an eye toward today's business challenges. Internal Auditor, 70(4), 60-66.

Kamarubahrin, A. F., Ahmed Ayedh, A. M., \& Khairi, K. F. (2019). Accountability Practices of Waqf Institution in Malaysia: A Critical Analysis, International Journal of Management, Accounting and Economics.6(2), 146-171.

Sulaiman, M. (2007). The Internal Control Procedures of Mosques in Malaysia. Revista Universo Contabil, 3(2), PP. $101-115$.

Spillan, J. E., \& Ziemnowicz, C. (2011). Who is in charge? Cases of not managing internal controls in nonprofit organizations. Journal of Business, Society \& Government, 3(1), 4-20.

Vance, A., Lowry, P. B., \& Eggett, D. (2015). Increasing Accountability Through User-Interface Design Artifacts. Mis Quarterly, 39(2), 345-366. 